4

\title{
TLQP Peptides in Amyotrophic Lateral Sclerosis: Possible Blood Biomarkers with a Neuroprotective Role
}

\author{
Carla Brancia, ${ }^{a *}$ Barbara Noli, ${ }^{a}$ Marina Boido, ${ }^{b}$ Roberta Pilleri, ${ }^{a}$ Andrea Boi, ${ }^{a}$ Roberta Puddu, ${ }^{\circ}$ Francesco Marrosu, \\ Alessandro Vercelli, ${ }^{b}$ Paolo Bongioanni, ${ }^{d}$ Gian-Luca Ferri ${ }^{a \dagger}$ and Cristina Cocco ${ }^{a \dagger}$ \\ ${ }^{a}$ Dept. Biomedical Sciences, University of Cagliari, Monserrato, Italy \\ ${ }^{\mathrm{b}}$ Neuroscience Institute Cavalieri Ottolenghi, Dept. Neuroscience, University of Turin, Turin, Italy \\ ${ }^{c}$ Dept. Neurology, Azienda Universitario Ospedaliera di Cagliari \& University of Cagliari, Cagliari, Italy \\ ${ }^{\mathrm{d}}$ Neurorehabilitation Unit, Dept. Neuroscience, University of Pisa, Pisa, Italy
}

\begin{abstract}
While the VGF-derived TLQP peptides have been shown to prevent neuronal apoptosis, and to act on synaptic strengthening, their involvement in Amyotrophic Lateral Sclerosis (ALS) remains unclarified. We studied human ALS patients' plasma (taken at early to late disease stages) and primary fibroblast cultures (patients vs controls), in parallel with SOD1-G93A transgenic mice (taken at pre-, early- and late symptomatic stages) and the mouse motor neuron cell line (NSC-34) treated with Sodium Arsenite (SA) to induce oxidative stress. TLQP peptides were measured by enzyme-linked immunosorbent assay, in parallel with gel chromatography characterization, while their localization was studied by immunohistochemistry. In controls, TLQP peptides, including forms compatible with TLQP-21 and 62, were revealed in plasma and spinal cord motor neurons, as well as in fibroblasts and NSC-34 cells. TLQP peptides were reduced in ALS patients' plasma starting in the early disease stage $(14 \%$ of controls) and remaining so at the late stage ( $16 \%$ of controls). In mice, a comparable pattern of reduction was shown (vs wild type), in both plasma and spinal cord already in the pre-symptomatic phase (about $26 \%$ and $70 \%$, respectively). Similarly, the levels of TLQP peptides were reduced in ALS fibroblasts (31\% of controls) and in the NSC-34 treated with Sodium Arsenite (53\% of decrease), however, the exogeneous TLQP-21 improved cell viability (SA-treated cells with TLQP-21, vs SA-treated cells only: about $83 \%$ vs. $75 \%$ ). Hence, TLQP peptides, reduced upon oxidative stress, are suggested as blood biomarkers, while TLQP-21 exerts a neuroprotective activity. $\odot 2018$ Published by Elsevier Ltd on behalf of IBRO.
\end{abstract}

Key words: TLQP-peptides, neurodegeneration, ALS, motor neurons, NSC-34 cells, human fibroblasts.

\footnotetext{
*Corresponding author. Address: NEF Lab, Dept. Biomedical Science, Cittadella Univers. 1, 09042 Monserrato, CA, Italy.

E-mail address: cbrancia@unica.it (C. Brancia).

Co-senior authors.

Abbreviations: ALS, Amyotrophic Lateral Sclerosis; ALSFRS-R, ALS Functional Rating Scale-Revised; C3AR, complement component 3a receptor 1; gC1q-R, receptor for the globular heads of c1q; DMEM, Dulbecco's modified Eagle's medium; EDTA, ethylenediaminetetraacetic acid; ELISA, enzyme-linked immunosorbent assay; ER, endoplasmic reticulum; MTT, 3-(4,5-Dime thylthiazol-2-yl)-2,5-Diphenyltetrazolium Bromide; NSC-34, mouse motor neuron-like hybrid cell line; PBS, phosphate-buffered saline; PIC, protease inhibitor cocktail; PFA, paraformaldehyde; SA, Sodium Arsenite; SOD1, superoxide dismutase 1; VAChT, vesicular acetylcholine transporter; TARDBP, TAR DNA-Binding Protein.
}

death ensues 3-5 years after appearance of the first symptoms. Currently, no treatment is effective in stopping the progression of the disease, nor is any early diagnostic test available. While the etiology of ALS is unknown, mutations of the superoxide dismutase 1 (SOD1) gene, or of the TARDBP (TAR DNA Binding Protein) gene have been hypothesized as common causes (Chiò et al., 2011; Zarei et al., 2015). In fact, oxidative stress, characterized by an altered equilibrium between the production of reactive oxygen species (free radicals) and antioxidant reactions, has been related to motor neuron degeneration in ALS (Bergeron, 1995; Robberecht, 2000). TLQP peptides are a family of peptides derived from the VGF (non acronymic) precursor protein, some of these originally identified in rat brain (Trani et al., 2002). They share a common $\mathrm{N}$-terminal "TLQP" (Thr-Leu-GIn-Pro) amino acid sequence, are cleaved from the primary VGF product at the specific RP-R (Arg-Pro-Arg) processing site found at rat/mouse VGF $_{553-555}\left(\right.$ VGF $_{551-553}$ in human), and variably extend 
to the VGF precursor C-terminus (Brancia et al., 2010). In the brain, TLQP peptides appear to show a restricted localization compared to other VGF-derived peptides, including a subpopulation of hypothalamic neurons projecting to a discrete area of median eminence (Brancia et al., 2010; Noli et al., 2014). Recently, a differential expression of several TLQP peptides was reported in the Syberian hamster brain. Namely, TLQP-21 (21 amino acid in length, rat $V_{\text {GF }}$ 556-576 ) was well represented in both hypothalamus and cortex while the longer form of TLQP-62 (rat VGF ${ }_{556-617}$ encompassing the VGF precursor's C-terminus) was abundant in cortex, and less expressed in hypothalamus (Noli et al., 2015). TLQP peptides were also found in hypothalamic-pituitary axis and plasma, differently expressed during the oestrous cycle phases (Noli et al., 2014) as well as in several peripheral locations including adrenal and stomach, changing in condition of stress and upon fasting, respectively (D'Amato et al., 2008; Brancia et al., 2010). Additional molecular forms compatible with predicted TLQP-30 and TLQP-42 peptides were revealed in certain endocrine organs (Cocco et al., 2007; Brancia et al., 2010) but have not been further studied so far. In human plasma, TLQP peptides were upregulated upon hyperglycemia, and downregulated in obese subjects (D'Amato et al., 2015). As to bioactivity and possible role/s, TLQP-21 has been shown to be involved in the regulation of metabolic mechanisms (Bartolomucci et al., 2006; Jethwa et al., 2007; Lewis et al., 2017), reproduction (Aguilar et al., 2013; Noli et al., 2014), chronic stress (Razzoli et al., 2012) and inflammatory pain (Rizzi et al., 2008). The same peptide prevented apoptosis of rat cerebellar granules upon serum and potassium deprivation, with modulation of kinase phosphorylation (Severini et al., 2008). Also, it protected human umbilical vein endothelial cells against high-glucose-induced apoptosis, by enhancing glucose6-phosphate dehydrogenase and nicotinamide adenine dinucleotide phosphate dehydrogenase, hence reducing reactive oxygen species (Zhang et al., 2013). Two receptor molecules have been identified for TLQP-21, namely the complement component $3 a$ receptor (C3a-R: Hannedouche et al., 2013; Cero et al., 2014, 2016) and the receptor for the globular heads of $\mathrm{c} 1 \mathrm{q}$ ( $\mathrm{gC} 1 \mathrm{q}-\mathrm{R}$ : Chen et al., 2013) and involved, with TLQP-21, in modulating lipolysis (Cero et al., 2016) and neuropathic pain (Chen et al., 2013), respectively. While the precise mechanisms involved are not entirely known, there is strong evidence that the TLQP-21 may act by increasing intracellular calcium in Chinese hamster ovary cells (Cassina et al., 2013), microglia (Chen et al., 2013) and cerebellum (Severini et al., 2008). The longer form of TLQP-62 has been widely investigated in hippocampus where it enhances synaptogenesis (Behnke et al., 2017), regulates memory formation, and induces both synaptic potentiation (Bozdagi et al., 2008; Lin et al., 2015) and neurogenesis (Thakker-Varia et al., 2014). It can also cause dorsal horn cell hyper-excitability and behavioral hypersensitivity in rats (Moss et al., 2008). No specific receptor has been identified so far for TLQP-62. In ALS, despite the reported evidence that VGF expression is modulated in the animal model and humans (Pasinetti et al., 2006; Zhao et al., 2008), limited information is available regarding TLQP peptides. We have previously reported the involvement of the VGF C-terminal peptides in ALS, modulated in the SOD1 mutant mice and patient's plasma, but exclusively at the final disease phase (Brancia et al., 2016). Afterward, we aimed at specifically investigating the role of the TLQP peptides in ALS, by studying their expression and changes (using ELISA and immunohistochemistry) in transgenic mice (SOD1G93A) and the mouse motor neuron-like hybrid cell line (NSC-34), as experimental models. In parallel, we also investigated, by ELISA, ALS patients' plasma and primary fibroblast cultures, the latter being considered a good cellular model used in human ALS research (Sabatelli et al., 2015; Yang et al., 2015) and also, contain VGF (Brancia et al., 2016). Moreover, in the NSC-34 cells, the neuroprotective role of the TLQP-21 was addressed in parallel with the presence of its two known receptors ( $g C 1 q-R$ and C3a-R), examined by both western blot and immunocytochemistry.

\section{EXPERIMENTAL PROCEDURES}

\section{Human subjects}

Subjects of Sardinian descent were studied, including ALS patients (females: $n=20$, males: $n=24$, age range: $25-85 \mathrm{yrs})$, and age-matched controls (unaffected by either neurological conditions, or diabetes; females: $n=20$, males: $n=26$ ). In patients, ALS-related mutations were studied as follows: exon 6 of the TARDBP gene, and all five coding exons of the SOD1 gene were screened by polymerase chain reaction and sequenced using the Big-Dye Terminator v3.1 kit (Applied Biosystems Inc) and an ABI Prism 3130 Genetic Analyzer. A repeat-primed polymerase chain reaction assay was used to screen for the GGGGCC hexanucleotide expansion in the first intron of C9ORF72 (DeJesus-Hernandez et al., 2011; Renton et al., 2011). ALS patients studied showed either: TARDBP-A382T mutation ( $n=16$ ), SOD1-G93A mutation $(n=3)$; expansion in the C9ORF72 gene $(n=5)$, or no identifiable ALS-related mutation $(n=20)$. The patients' motor and functional (which incorporates additional assessments of dyspnea, orthopnea, and the need for ventilatory support) performance was assessed at the time of blood sampling, by at least two experienced neurologists, according to the ALS Functional Rating Scale Revised (ALSFRS-R: Cedarbaum et al., 1999). Patients' data (summarized in Appendix A: Table 1A), including: age, gender, genetic mutation, ALSFRS-R score and co-morbidity at the time of blood sampling, as well as their clinical condition one year later (whether alive, or not, with or without tracheostomy). On the latter basis, patients were assigned to either group I, "early disease stage" $(n=25)$ : patients who were alive and free of tracheostomy one year after blood sampling; or group II, "late disease stage" $(n=19)$ : patients who were deceased, or had undergone tracheostomy. The present study was approved by the Ethics Committee at the Cagliari AOU ("Azienda Ospedaliero Universitaria di Cagliari”), protocol n. 450/09/C.E. All patients provided 
their written informed consent to be part of the study according to the Italian legislation.

\section{Human samples}

Blood samples were collected with ethylenediaminetetraacetic acid (EDTA, $1.5 \mathrm{mg} / \mathrm{ml}$ ), rapidly centrifuged $(14,000 \mathrm{rpm}, 5 \mathrm{~min})$, hence plasma was aliquoted and stored frozen (at $-80^{\circ} \mathrm{C}$ ). Fibroblast primary cultures were set up using skin biopsies (taken under local anesthesia) obtained from "late disease stage" ALS patients ( $n=4$ : two showed a heterozygous missense TARDBP-A382T mutation, two showed no identifiable ALS-related mutation), and age-matched controls $(n=3)$. Cultures were grown as previously reported (Orrù et al., 2016), using high-glucose Dulbecco's modified Eagle's medium (DMEM) supplemented with fetal bovine serum $(20 \% \mathrm{vol} / \mathrm{vol})$ and penicillin/streptomycin (10 ml/L of: 10,000 U penicillin $+10 \mathrm{mg} / \mathrm{ml}$ streptomycin in $150 \mathrm{mmol} / \mathrm{L} \mathrm{NaCl}$ ). Oxidative stress was induced adding sodium Arsenite (SA) to the culture medium $(0.5 \mathrm{mmol} / \mathrm{L}$, for $60 \mathrm{~min})$. For ELISA, cultures were expanded, and four culture plates per patient (or control), and per treatment (SA, or no treatment), were separately extracted in phosphate-buffered saline (PBS: $0.01 \mathrm{~mol} / \mathrm{L}$ $\mathrm{PO}_{4}, \mathrm{pH} 7.2,0.15 \mathrm{~mol} / \mathrm{L} \mathrm{NaCl}$ ) containing a protease inhibitor cocktail (PIC, Sigma-Aldrich P8340, $10 \mathrm{ml} / \mathrm{g}$ tissue). Remaining extracts (from controls' explants) were pooled and used for gel chromatography.

For immunocytochemistry, cells were grown on coverslips, and at least three coverslips (per patient/control, and per treatment) were fixed in paraformaldehyde (PFA: $40 \mathrm{~g} / \mathrm{L}$ in PBS, $15 \mathrm{~min}$ ), permeabilized with cold methanol $(5 \mathrm{~min})$, hence Triton $X-100(20 \mathrm{ml} / \mathrm{L}$ in PBS, $20 \mathrm{~min})$, and rinsed with PBS. Coverslips were immunostained for TLQP peptides, and with a HuR antibody (Santa Cruz, Antibody Registry: $A B 627770$, raised in mouse, 1:500) to label stress granules, while nuclei were counterstained with bisBenzimide (Hoechst 33342, $0.5 \mu \mathrm{g} / \mathrm{ml}$ in PBS).

\section{SOD1-G93A mice}

Transgenic B6SJL-TgN(SOD1-G93A)1Gur mice were used, over-expressing human SOD1 containing the Gly $_{93}$ to Ala mutation (Jackson Laboratory, Bar Harbor, ME, USA; stock number 002726; housed at the University of Turin animal house facilities). All experimental procedures on live animals were carried out in accordance with the European Communities Council Directive 86/609/EEC (November 24, 1986), and the Italian Ministry of Health and University of Turin institutional guidelines on animal welfare (law 116/92 on Care and Protection of living animals undergoing experimental or other scientific procedures; authorization number $17 / 2010-B$, June 30, 2010). The Ethics Committee at the University of Turin approved the study. All possible efforts were made to minimize the number of animals used and their suffering. Animal genotyping and behavioral testing used to assess disease progression (neurological test, rotarod and paw grip endurance tests) were previously described in detail
(Boido et al., 2014). Transgenic animals were grouped according to age (days postnatal: $P$ ) and stage of motor dysfunctions (Brancia et al., 2016), as follows: (i) presymptomatic (around P45); (ii) early-symptomatic (around P90; two repeated deficits for two consecutive times); (iii) late-symptomatic (around $\mathrm{P} 120 ; \geq 20 \%$ weight loss and inability to perform tests). Age-matched wild-type mice were used as controls: groups (iv) through (vi), respectively. Male mice were used in all cases, in view of our previous finding of TLQP modulations in female rodents along the oestrous cycle (Noli et al., 2014).

For ELISA and gel chromatography, animals $(n=7$ per group) were anesthetized (3\% isoflurane vaporized in $\mathrm{O}_{2} / \mathrm{N}_{2} \mathrm{O} 50: 50$ ), hence blood was drawn by cardiac puncture, collected in EDTA-containing tubes $(1.78 \mathrm{mg} /$ $\mathrm{ml}$ ), and centrifuged $(11,000 \mathrm{rpm}, 5 \mathrm{~min})$. Plasma was aliquoted and stored frozen $\left(-80^{\circ} \mathrm{C}\right)$. Upon blood sampling, animals were euthanized by cervical dislocation, and spinal cords were dissected. Tissues were coarsely minced with a scalpel, collected in tubes with ice-cold PBS containing PIC (10 ml/g tissue), treated with an Ultra-Turrax tissue homogenizer (lkaWerke, Staufen, Germany, $3 \mathrm{~min}$ ), hence tubes were heated in a vigorously boiling water bath $(10 \mathrm{~min})$, and centrifuged $(3000 \mathrm{rpm}, 15 \mathrm{~min})$. Supernatants were stored frozen until use $\left(-20^{\circ} \mathrm{C}\right)$. For immunohistochemistry, mice ( $n=3$ per group) were anesthetized as above, and perfused transcardially with PFA (10 min). The whole spinal cord was removed and post-fixed in PFA (at $4{ }^{\circ} \mathrm{C}, 2 \mathrm{~h}$ ). Cryosections of cervical and lumbar spinal cord (8- $\mu \mathrm{m}$ thickness) were immunostained (in single and double immunofluorescence) for TLQP peptides, and with an antibody to vesicular acetylcholine transporter (VACht, BIOMOL Research lab, Antibody Registry: AB2052813, raised in goat, $1: 400)$ to label cholinergic motor neurons.

\section{NSC-34 cells and oxidative stress}

Cells were grown in high-glucose DMEM, supplemented with fetal bovine serum $(10 \% \mathrm{vol} / \mathrm{vol})$ and penicillin/ streptomycin (as for fibroblasts, see above). For testing, cells were plated at a $50,000 / \mathrm{ml}$ density in 24-well plates $(24 \mathrm{~h})$, hence underwent oxidative stress by addition of SA $(0.5 \mathrm{mmol} / \mathrm{L}$ in culture medium, $60 \mathrm{~min}$ at $37^{\circ} \mathrm{C}$ ) and measured the levels of TLQP-21, NERP-1, NAPP- and APGH-peptides, as well as VGF N-terminus and C-terminus. The effect of TLQP-21, NERP-1 (synthetic, custom produced for us by CPC Scientific, Sunnyvale, CA, USA) was assessed by addition to the culture media, in the presence/absence of $S A$, at a range of concentrations $(0.1-10 \mathrm{nmol} / \mathrm{ml})$. Cell proliferation and viability was assessed used a colorimetric method based on the 3-(4,5-Dimethylthia zol-2-yl)-2,5-Diphenyltetrazolium Bromide reagent (MTT test, Sigma-Aldrich), according to the manufacturer's protocol. Absorbance was measured at $570 \mathrm{~nm}$ (EnVision plate analyzer, Perkin Elmer, Milan, Italy). For ELISA and gel chromatography, cell preparations were extracted with PBS containing PIC (10 ml/g tissue), as described for fibroblasts. For immunocytochemistry, preparations grown on glass coverslips were fixed with 
PFA (10 min), permeabilized with cold methanol (5 min), then with Triton X-100 (10 ml/L in PBS, $20 \mathrm{~min})$, and rinsed in PBS. Coverslips were immunostained for TLQP peptides, and for the TLQP-21 receptors: gC1q-R (Abcam, Antibody Registry: AB10675815, raised in rabbit, 1:600), and C3a-R (Abcam, Antibody Registry: AB2687440, raised in rabbit, 1:200-1000). A HuR antibody (Santa Cruz, Antibody Registry: AB627770, raised in mouse, 1:500), to label stress granules, and a calnexin antibody (Sigma-Aldrich, Antibody Registry: AB2069152, raised in mouse, 1:300), to label endoplasmic reticulum (ER), were used in doubleimmunostaining with the TLQP antiserum. Cell nuclei were counterstained with bisBenzimide (Hoechst 33342, $0.5 \mu \mathrm{g} / \mathrm{ml}$ ).

\section{TLQP peptide/s antiserum}

The guinea-pig primary antiserum to TLQP peptides, specific for their common $\mathrm{N}$-terminal portion, previously described in detail (Brancia et al., 2005) was extensively used in different organs and tissues (Cocco et al., 2007, D'Amato et al., 2008, 2015; Brancia et al., 2010; Noli et al., 2014; Noli et al., 2017). Briefly, a synthetic peptide corresponding to rat $\mathrm{VGF}_{556-564}$, with the addition of a Cterminal cysteine residue, was conjugated via its $\mathrm{C}$ terminus to keyhole limpet hemocyanin $(\mathrm{KLH})$, and used for immunizations. See ELISA and immunohistochemistry sections (below), for specificity controls relevant to its use in each method.

\section{ELISA}

Competitive ELISA was carried out as previously described in detail (Cocco et al., 2007), and the characterization of the TLQP assay are summarized in Table 1, while calibration curve is shown in Fig. 1. Briefly, multiwell plates (Nunc Thermoscientific, Milan, Italy) were coated with the relevant synthetic peptide, hence treated with PBS containing normal donkey serum $(90 \mathrm{ml} / \mathrm{L})$, aprotinin $(20 \mathrm{nmol} / \mathrm{L})$, and EDTA $(1 \mathrm{~g} / \mathrm{L})$ for $2 \mathrm{~h}$. Primary incubations (3h) were carried out in duplicate, using TLQP (1:5k), NERP-1 (1:160 k; Cocco et al., 2007), NAPP (1:100 k; D'Amato et al., 2015) as well as N-terminus and C-terminus (both 1:12 k; Cocco et al., 2010) antisera followed by biotinylated secondary antibodies (Jackson, West Grove, PA, Antibody registry: AB2340451; 1:10 K, $1 \mathrm{~h}$ ), streptavidin-peroxidase conjugate (Biospa, Milan, Italy, $30 \mathrm{~min}$ ), and tetramethylbenzidine substrate (TMB X-traKem-En-Tec, Taastrup, Denmank, $100 \mathrm{ml} /$ well). Reaction was stopped with $\mathrm{HCl}(1 \mathrm{~mol} / \mathrm{L})$ and optical density was measured at $450 \mathrm{~nm}$ using a multilabel plate reader (Chameleon: Hidex, Turku, Finland). Recovery of synthetic peptide (same used for immunization, plate coating and measurement standard) added to plasma, or to tissue samples at extraction was $>85 \%$.

\section{Gel chromatography}

Plasma samples (human: $2 \mathrm{ml}$, or a pool from control mice: $1 \mathrm{ml}$ ), as well as extracts of spinal cord (pooled from control mice: $1.6 \mathrm{ml}), \mathrm{NSC}-34$ cells $(2 \mathrm{ml})$ and fibroblasts $(1.2 \mathrm{ml})$ were individually loaded onto a Sephadex G-50S column (Sigma-Aldrich, $2 \mathrm{~cm}^{2} \times 1 \mathrm{~m}$ ). The column was equilibrated with ammonium bicarbonate solution $\left(50 \mathrm{mmol} / \mathrm{L}\right.$ in $\mathrm{H}_{2} \mathrm{O}$ ) and eluted with the same buffer (about $0.3 \mathrm{ml} / \mathrm{min}$, using a membrane pump running at $5 \mathrm{impulses} / \mathrm{min},-4{ }^{\circ} \mathrm{C}$ ). The column was calibrated using a kit (MVGF70, Sigma-Aldrich) containing the following molecular weight markers: bovine albumin $(66 \mathrm{kDa})$, carbonic anhydrase (29 kDa), cytochrome c $(12.4 \mathrm{kDa})$, and aprotinin $(6.5 \mathrm{kDa})$. Collected fractions $(3 \mathrm{ml})$ were reduced in volume using a Vacufuge Concentrator (Eppendorf, Milan, Italy) and assessed by ELISA. Experiments were carried out in duplicate, or in triplicate, depending on sample availability. Overall recovery of loaded immunoreactive material/s resulted in an $81-102 \%$ range.

\section{Detection of TLQP peptides in tissues and cells}

TLQP antiserum (1:600-1:800) was diluted with PBS containing normal donkey serum $(30 \mathrm{ml} / \mathrm{L}$, from a pool of $>5$ animals) and $\mathrm{NaN}_{3}(0.5 \mathrm{~g} / \mathrm{L})$, with the addition of normal mouse serum (30 $\mathrm{ml} / \mathrm{L}$ : mouse tissue sections only). Primary incubations were carried out at room temperature, either overnight ( $16 \mathrm{~h}$ : mouse spinal cord sections), or for $4 \mathrm{~h}$ (fibroblast and NSC-34 cell cultures). For double-labeling, the relevant primary antibodies were mixed and similarly incubated (see specific part). Sites of primary immune reaction were revealed using secondary lgG preparations absorbed against serum proteins from multiple species (Jackson Immunoresearch Laboratories, West Grove, PA, USA), at a $2-10 \mathrm{mg} / \mathrm{L}$ concentration (in PBS, $1 \mathrm{~h}$ at room temperature). As appropriate, either of the following was used (1:200-300): (a) Cyanin 3.18-conjugated donkey anti-guinea pig IgG (Antibody registry: AB2340460), (b) Cyanin 3.18, or Alexa488-conjugated anti-mouse IgG (Antibody registry: AB2340460 and AB2341099, respectively), (c) a mixture of "a" and "b" above, (d) Cy3-conjugated anti-rabbit IgG (Antibody registry: $A B$ 2307443) (e) Alexa488-conjugated donkey anti-sheep IgG (Antibody registry: AB 2340754). Routine controls included: substitution of each antibody layer, in turn, with PBS; the use of pre-immune, or non-immune sera; the use of inappropriate secondary antibodies. Preabsorption of the TLQP antiserum with the relevant (unconjugated) peptide (up to $100 \mathrm{mmol} / \mathrm{L}$ ) resulted in virtually complete prevention of the corresponding labeling. Slides were coverslipped, and culture coverslips were mounted on slides, using Glycerol-PBS (1:2) containing $\mathrm{NaN}_{3}(0.2 \mathrm{~g} / \mathrm{L})$. Preparations were observed and photographed using a BX51 fluorescence microscope (Olympus, Milan, Italy) equipped with a Fuji S3 Pro digital camera (Fujifilm, Milan, Italy).

\section{Western blot of TLQP-21 receptors}

NSC-43 cell preparations were lysed in $2 \%$ sodium dodecyl sulfate $(20 \mathrm{~g} / \mathrm{L}, \mathrm{min})$, and a sample $(10 \mu \mathrm{l})$ was set aside to assess protein concentration (BCA assay, Thermo Scientific). Loading buffer $(75 \mathrm{mmol} / \mathrm{L}$ trishydrogen chloride buffer, $\mathrm{pH} 6.8$, containing $200 \mathrm{ml} / \mathrm{L}$ 
Table 1. VGF assay characterization

\begin{tabular}{|c|c|c|c|c|c|}
\hline Assay & Peptide & $\mathrm{IC}_{50}$ & CV1 \% & $\mathrm{CV} 2 \%$ & CR \% \\
\hline \multirow[t]{6}{*}{ TLQP } & rVGF$_{556-564}^{1}$ & 8 & $2-3$ & $7-3$ & 100 \\
\hline & rVGF $_{555-564}(\mathrm{R}-\mathrm{TLQPPASSR})^{*}$ & & & & 3.5 \\
\hline & rVGF $_{557-564}(-$ LQPPASSR $)$ & & & & 20 \\
\hline & $\mathrm{rVGF}_{556-565}(\mathrm{TLQP} 11)$ & & & & 122 \\
\hline & rVGF $_{556-576}(\mathrm{TLQP} 21)$ & & & & 183 \\
\hline & hVGF $_{554-577}($ TLQP24) & & & & 65 \\
\hline
\end{tabular}

$\mathrm{IC}_{50}$ : concentration of peptide producing $50 \%$ inhibition of the maximum signal (picomoles/milliliters); CV1 and CV2: intra- and inter-assay variation, respectively; $\mathrm{r}$ : rat; $\mathrm{h}$ : human " "reference" peptide used for immunization, plate coating, and standard. "Arginine (R): residue added at the peptide N-terminus, to mimic its extended sequence within the VGF precursor. The cross-reactivity (CR) of each peptide is expressed compared to the "reference" peptide, a $>100 \%$ reactivity is indicated for the authentic TLQP-21 that is more reactive compared to the reference one. CV1: mean values of six different known concentrations of TLQP calibrators (500 pmol/ml, $50 \mathrm{pmol} / \mathrm{ml}, 5 \mathrm{pmol} /$ $\mathrm{ml}, 0.5 \mathrm{pmol} / \mathrm{ml}, 0.05 \mathrm{pmol} / \mathrm{ml}, 0.005 \mathrm{pmol} / \mathrm{ml} ; 8$ replicates). CV2: three known calibrators ( $50 \mathrm{pmol} / \mathrm{ml}, 5 \mathrm{pmol} / \mathrm{ml}, 0.5 \mathrm{pmol} / \mathrm{ml} ; 10$ independent experiments, in duplicate).

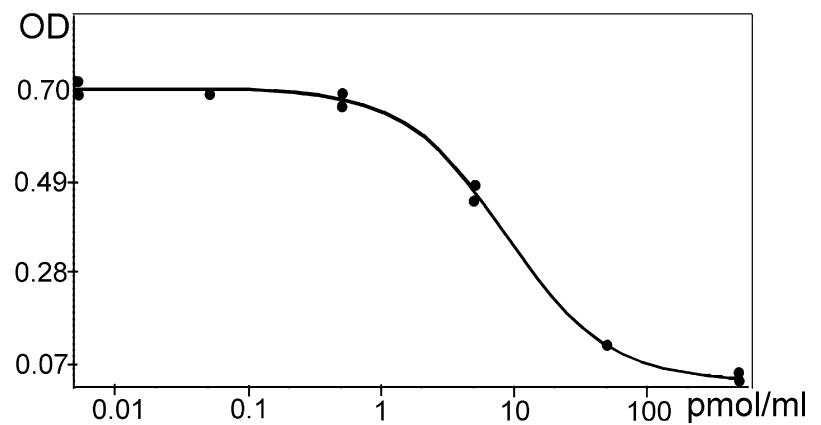

Fig. 1. Calibration curve. The standard curve was obtained using a range of concentrations of the "reference" peptide in solution $\left(V F_{556-564}\right)$ and a fixed amount of the same peptide onto the well, competing for the TLQP antibody, OD: optical density; pmol/ml: picomoles/milliliters.

glycerol, $0.4 \mathrm{~g} / \mathrm{L} \%$ SDS, $5 \%$-mercaptoethanol, $0.001 \%$ bromophenol blue) was added to the extract, hence tubes were heated in a vigorously boiling water bath (3 min). Samples (containing about $15 \mu \mathrm{g}$ proteins each) were loaded onto $4-20 \%$ gradient SDS (sodium dodecyl sulfate)-polyacrylamide gels and blotted onto polyvinylidene fluoride membranes (Hybond-P, Amersham). Membranes were blocked with 5\% non-fat dry milk (50 g/L, $1 \mathrm{~h}$, in PBS) and incubated overnight $\left(16 \mathrm{~h}\right.$, at $\left.4{ }^{\circ} \mathrm{C}\right)$ with either of the TLQP-21 receptor antibodies (see above: NSC-34 cell cultures). On the following day, membranes were incubated with horserad ish-peroxidase-conjugated anti-rabbit IgG (Invitrogen, Life Technologies, 1:5000, $1 \mathrm{~h}$ ), hence revealed using a chemiluminescent substrate (Euroclone, SpA, Pero, Milan). A rabbit anti-actin antibody (Sigma-Aldrich, Antibody Registry: AB476697, 1:1000) was used to confirm an equal protein loading. Runs were carried out in triplicate in different days.

\section{Statistical analyses}

Statistical analyses were carried out using the StatistiXL software. For each experimental set, the normality of data distributions was preliminary checked using the Goodness-of-fit test. Resulting $p$ values were $>0.05$ in all cases, hence the following parametric tests were applied. In case of unequal variance, the Welch $t$-test ( $t_{w}$-test) was carried out, otherwise the two-tailed
Student $t$-test with pooled variances was applied. Linear regression analysis was used to estimate possible correlations between plasma TLQP peptides, versus ALSFRS-R rating or the patients' age. In all cases, $p$-values $<0.05$ were deemed significant.

\section{RESULTS}

\section{TLQP peptides in human}

In plasma, levels of TLQP peptide immunoreactivity were roughly $80-90 \mathrm{pmol} / \mathrm{ml}$ in control subjects. A distinct, reduction in plasma TLQP peptides was seen in ALS patients (Fig. 2A), already in the early stage (mean $\pm E$ S, controls: $87.2 \pm 4.3$; patients: $75.1 \pm 4.0, t_{\mathrm{w}}$ test: $p$ $<0.05, \mathrm{DF}=65.4$, ) as also in the late stage (patients: $73.5 \pm 3.8, t_{\mathrm{w}}$ test: $p<0.05$, DF: 57.3). Data are expressed as percentage of the control samples $(100 \%)$. In gel chromatography, the following profile of TLQP immunoreactivity was revealed (Fig. 2B): (i) a major peak at a $\sim 7$ - to $8-\mathrm{kDa}$ elution position compatible with TLQP-62 (c) (ii) a broad peak in the $6.5-$ to $4-\mathrm{kDa}$ region probably corresponding with the TLQP-42 and 30 forms (d-e), and a lower peak at $\sim 2$ to 3-kDa compatible with TLQP-21 (f). Two larger forms were also found close to the void volume, at about 66and $14-$ to $15-\mathrm{kDa}$ elution positions may compatible to the VGF precursor (peak "a") and NAPP-129 (peak "b"), respectively, both including the internal TLQP sequence. The sequences of the above TLQP peptides are summarized in Fig. 3. No correlation was found between patients' plasma TLQP peptide levels and their corresponding ALSFRS-R score, age, or sex (Fig. 2CE). In fibroblasts (Fig. 2F-I) a significant reduction in TLQP peptide/s immunoreactivity (pmol/ $\mu$; controls: 0.3 $5 \pm 0.04$, ALS: $0.24 \pm 0.02$, $t$-test: $p<0.05$, DF $=19$ ) was shown in culture extracts from ALS patients compared to controls (Fig. 2F). TLQP peptide/s immunoreactivity was revealed in a region of cytoplasm close to the nucleus, bona fide the Golgi area, as previously shown (Brancia et al., 2016) and in agreement with the role of VGF as precursor of secretory products (Brancia et al., 2005). In both ALS patients and controls (Fig. 2G, H; respectively) cytoplasmic stress granules appeared after SA treatment as previously reported (Orrù et al., 2016). Such granules were not labeled by the TLQP antibodies (Fig. 2I). The molecular forms seen 

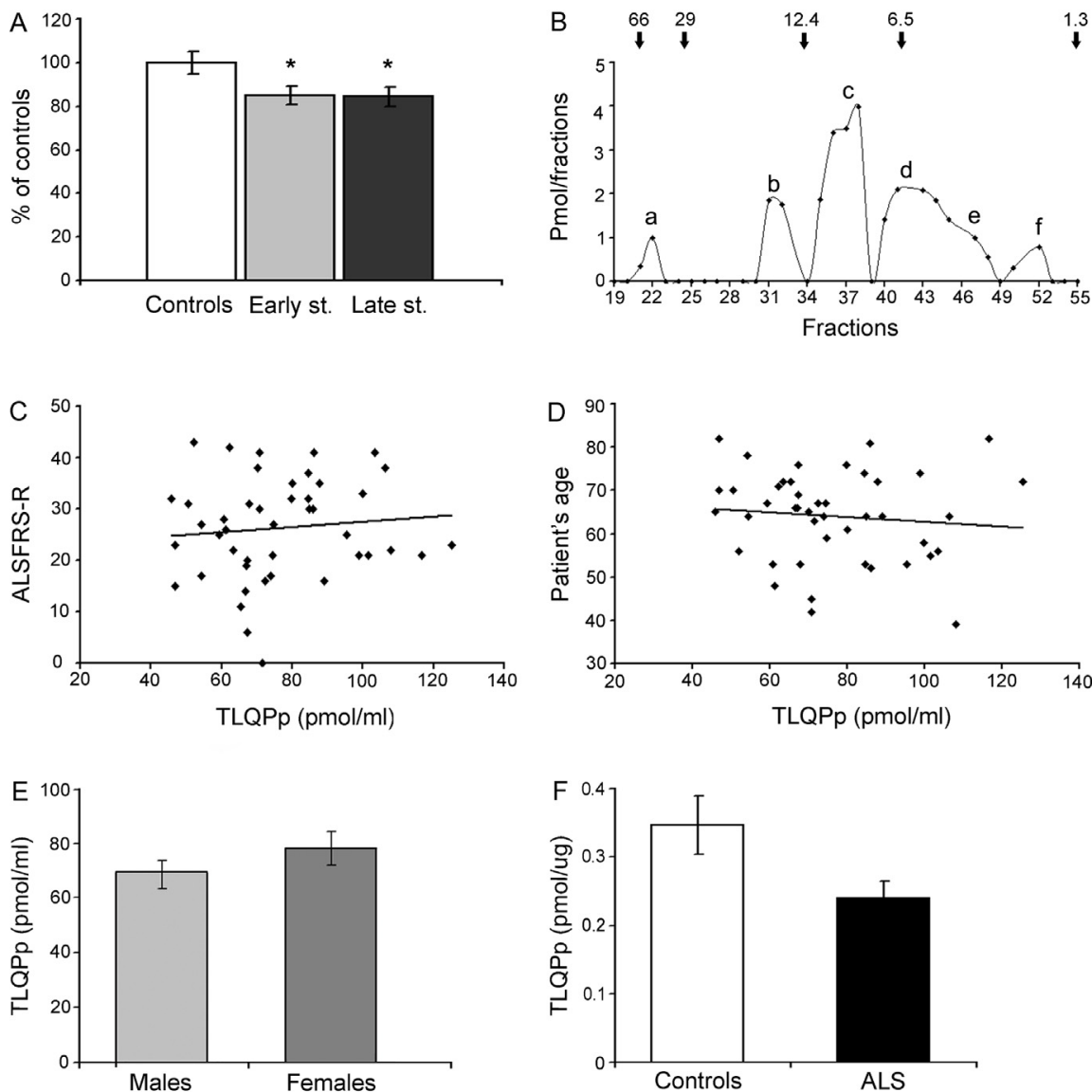

G
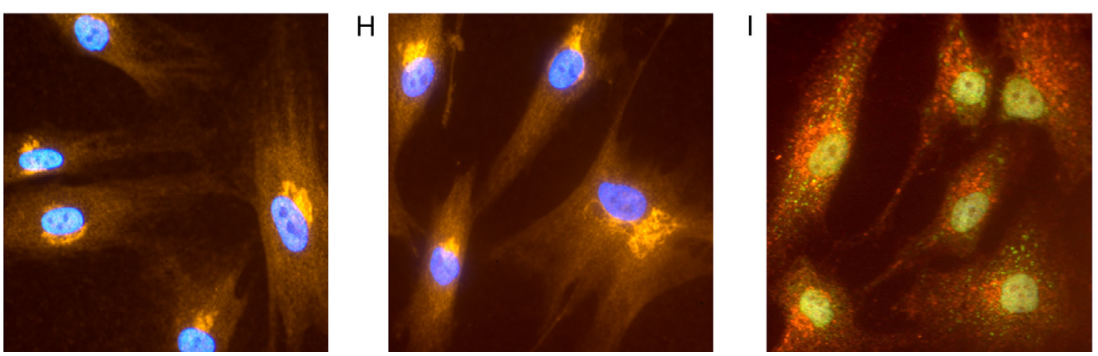

Fig. 2. TLQP peptides in human. Plasma levels of TLQP peptides (A). The levels of TLQP peptides in the early and late stage of the ALS patients ( $n=25$ and 19, respectively) are both reduced, when compared with the controls $(n=46)$; percentage of reduction: 14 and 16, early and late stage, respectively, $t_{\mathrm{w}}$ test: $p<0.05$. Data are expressed as percentage of the control samples (100\%). Chromatographic analysis coupled with ELISA (B). The following molecular forms are recognized by the TLQP-antiserum: a. $\sim 66 \mathrm{kDa}$, probably the VGF precursor; b. $\sim 15$ kDa compatible to NAPP-129, as well as: c. $\sim 7-8 \mathrm{kDa}$, d-e. $\sim 6.5-4 \mathrm{kDa}$, f. $\sim 2-3 \mathrm{kDa}$, compatible to TLQP-62, 42, 30 and 21, respectively. Arrows in the top indicates the molecular weight markers, pmol: picomoles. ALS Functional Rating Scale Revised (ALSFRS-R) vs. TLQP peptides levels (C) There is not a statistically significant linear relationship $(p \leq 0.427, R=0.124)$ between TLQP peptides levels and the ALSFRS-R values; $\mathrm{pmol} / \mathrm{ml}$ : picomoles/milliliter. Patient's ages vs. TLQP peptides levels (D). We observe a no statistically significant linear relationship $(p \leq 0.507 ; R=$ 0.103 ) between TLQP peptides levels and patient's ages. TLQP peptides levels in female and male ALS patients (E). A no significant difference is found between males and females ALS patients $(p>0.05)$. TLQP in fibroblasts $(\mathrm{F}-\mathrm{l})$. TLQP peptides are reduced $(\mathrm{F})$ in naïve ALS patient-derived cells $(n=4)$ compared to the corresponding controls $(n=3 ; \sim 31 \%$ of controls; $t$ test: $p<0.05) \mathrm{pmol} / \mathrm{\mu g}$ : picomoles/micrograms. TLQP peptides are present in specific cytoplasm structures, probably the Golgi area, in cells from controls as well as ALS patients ( $\mathrm{G}$ and $\mathrm{H}$ respectively; red-orange, Cy3), either before $(\mathrm{H})$ or after the treatment with $\mathrm{SA}(\mathrm{I})$, that produces visible stress granules (revealed with anti HuR, green, Alexa-488). The nuclei are revealed in Blue (Hoechst 33342). (For interpretation of the references to color in this figure legend, the reader is referred to the web version of this article.)
3 upon gel chromatography were broadly comparable to those found in plasma (data not shown).

\section{TLQP peptides in mice}

In the cervical spinal cord of wild-type mice of all ages studied, TLQP peptides were well represented in large- and medium-sized perikarya in laminae VIII and IX, the majority surrounded by the VAChT staining, hence identified as motor neurons (Fig. 4A, white arrows) while their levels (through ELISA) were in a range of $100-250 \mathrm{pmol} / \mathrm{g}$. Instead, in the mutant mice, the TLQP immunoreactivity was significantly decreased, through both IHC (Fig. 4A) and ELISA in the pre-symptomatic stage $(158.7 \pm 15.1$ and $46.6 \pm 20.4$, wild type vs. SOD1, $t$-test: $p<0.005$, $\mathrm{DF}=9)$, remaining down regulated up to the late stage (WT:186.8 \pm 10.6 SOD1: $153.5 \pm 19.9$, t-test: $p<$ 0.05 , DF = 10) (Fig. 4B). Lumbar and cervical spinal cords were analyzed in parallel showing similar immunostaining profiles in both $\mathrm{IHC}$ and ELISA. The molecular forms recognized by the TLQP antiserum were comparable to those observed in human samples, including peaks compatible with TLQP-62,-42,-30,-21 (peaks $c-f$ ) and the two peaks, "a" and "b", may be compatible with the VGF precursor and NAPP-129, respectively (Fig. 4C). In all wild-type mice, plasma concentrations of TLQP peptides ranged between 170 and $200 \mathrm{pmol} / \mathrm{ml}$, while they were significantly decreased in SOD1mutant mice at the pre-symptomatic stage (WT: $170.5 \pm 17.8$, SOD1: 125. $7 \pm 8.8$, t-test: $p<0.05, \quad \mathrm{DF}=10$ ), remaining reduced in the late stage (WT: $171.5 \pm 9.8$, SOD1: $132.3 \pm 12$ 1, $t$-test: $\quad p<0.05, \quad \mathrm{DF}=10$ ) (Fig. 4D). Gel chromatography applied to the mouse plasma revealed similar forms observed in human and mouse spinal cord hence it was not shown.

\section{TLQP peptides and NSC-34 cells}

TLQP immunoreactivity was found in the growth cones and axons of NSC34 cells, as well as in their cytoplasm in a para-nuclear location suggestive of its abundance in the bona fide 


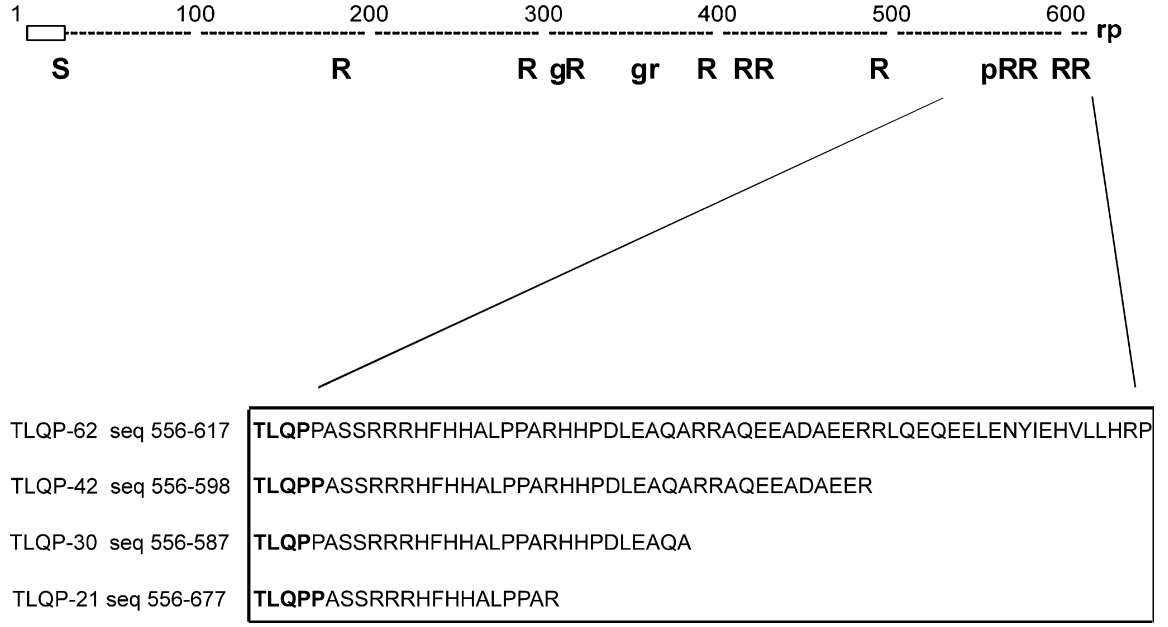

Fig. 3. TLQP sequences. The different sequences of the putative TLQP peptides are described.

Golgi area (Fig. 5A left panel). No co-localization was found with markers of the ER (data not shown). Upon treatment with $\mathrm{SA}$, to induce oxidative stress, cells mostly lost their axons and growth cones changing to a round shape while TLQP peptides maintained their cytoplasmic localization (Fig. 5A, middle panel). No TLQP immunoreactivity was detected in stress granules (Fig. 5A, right panel). A significant decrease in TLQP peptides content ( $\mathrm{pmol} / \mu \mathrm{g}$ total protein; Fig. $5 \mathrm{~B}$ ) was found in SA-treated cells (naïve: $0.199 \pm 0.04$, treated: $0.094 \pm 0.01, t_{\mathrm{w}}$ test: $p<0.05, \mathrm{DF}=9$ ). Addition of synthetic TLQP-21 $(1 \mathrm{nmol} / \mathrm{ml})$ to culture media of SAtreated cells significantly increased cell viability, compared to the SA treatment only $(82.5 \%$ vs. $74.7 \%$, $p<0.05$; Fig. 5C). Several VGF-derived peptides were measured in naive and SA-stressed cells. Further to TLQP peptides, these included NERP-1, NAPP and APGH peptides, as well as VGF N-terminus- and Cterminus-related peptides. Only TLQP and NERP-1 peptide/s showed a significant change (reduction) in stressed cell cultures, hence were tested. However, addition of synthetic NERP-1 to the cell culture medium did not result in any detectable change in cell viability (data not shown). When we used the antibodies against the two TLQP receptors, the gC1q-R antibody showed a labeling in the nucleus with a feeble immunostaining into the cytoplasm (Fig. 5D), as expected (Soltys et al., 2000) while a weak staining only was revealed for C3a$R$. The presence of $\mathrm{gC} 1 \mathrm{q}-\mathrm{R}$ (predicted molecular weight: $33 \mathrm{kD}$ ) was confirmed by western blot analysis (Fig. 5E). NSC-34 extracts revealed approximately the same MW forms observed in human and mouse samples, hence they were not shown.

\section{DISCUSSION}

We demonstrate here a downregulation of TLQP peptides in both stressed NSC-34 cells and untreated fibroblast cultures from ALS patients, as well as in motor neurons of SOD-1 mice before the onset of significant muscle weakness. In plasma, TLQP peptides were also reduced from the early clinical stages in ALS patients, and so were in the earliest stage studied in SOD-1 mice (pre-symptomatic stage). Hence, plasma TLQP peptides may have a value as possible biomarkers in the screening or diagnosis of suspected ALS patients.

\section{TLQP peptides as blood biomarkers}

The identification of potential biomarkers sensitive to the progression of disease is one of the present goals of ALS research. In SOD-1 mice, the reduction in TLQP peptide/s we observed in both plasma and motor neurons at the earliest, pre-symptomatic stage suggests that plasma changes may not only parallel, but also reflect early changes occurring in motor neurons. Hence, peptides of the overall TLQP family may show promise as indicators for early diagnosis of ALS. In fact, measurement of most neurotrophic factors, including BDNF (Tremolizzo et al., 2016), failed to selectively detect ALS patients and changes at an early phase (Turner et al., 2009). In a previous study, we revealed changes in peptides derived from a different part of VGF, namely the region encompassing the C-terminal end of the VGF precursor (Brancia et al., 2016). VGF Cterminus peptides also showed significant changes in ALS patients, but only at the advanced clinical stage (Brancia et al., 2016). Hence, it is conceivable that other VGF-derived peptides, including those related to the VGF C-terminus, may decrease upon an extensive neuronal damage, while TLQP peptides are reduced at an earlier stage of initial cellular damage or breakdown. While further studies will be required, with the precise identification of the molecular forms involved, one might suggest that TLQP-21 and other related peptides, i.e., TLQP-62, could be most prominently involved in the overall changes found in the present paper. The TLQP-62 peptide, deserves a special mention, because, since it extends from the TLQP sequence to the full C-terminus of the VGF precursor, it is also recognized and measured by VGF C-terminus assay (Brancia et al., 2016). Moreover, since the Sardinian population has a high predominance of TARDBP mutation (Chiò et al., 2011), as reflected in our cohort of patients, we were not able to study any correlation between TLQP levels and specific ALS mutation/s. While future studies will be done by us to investigate if the reduction in TLQP peptides is peculiar for ALS, schizophrenia induced by phencyclidine has not produced any TLQP changes in the rat blood (Noli et al., 2017).

\section{TLQP peptides are reduced in ALS tissues}

TLQP peptides were reduced in spinal cord motor neurons of SOD1-G93A mice, in SA-stressed NSC-34 cells, as well as in fibroblast cultures from ALS patients. Interestingly, the latter patients showed a TARDBP mutation, which has also been proposed to induce cell 

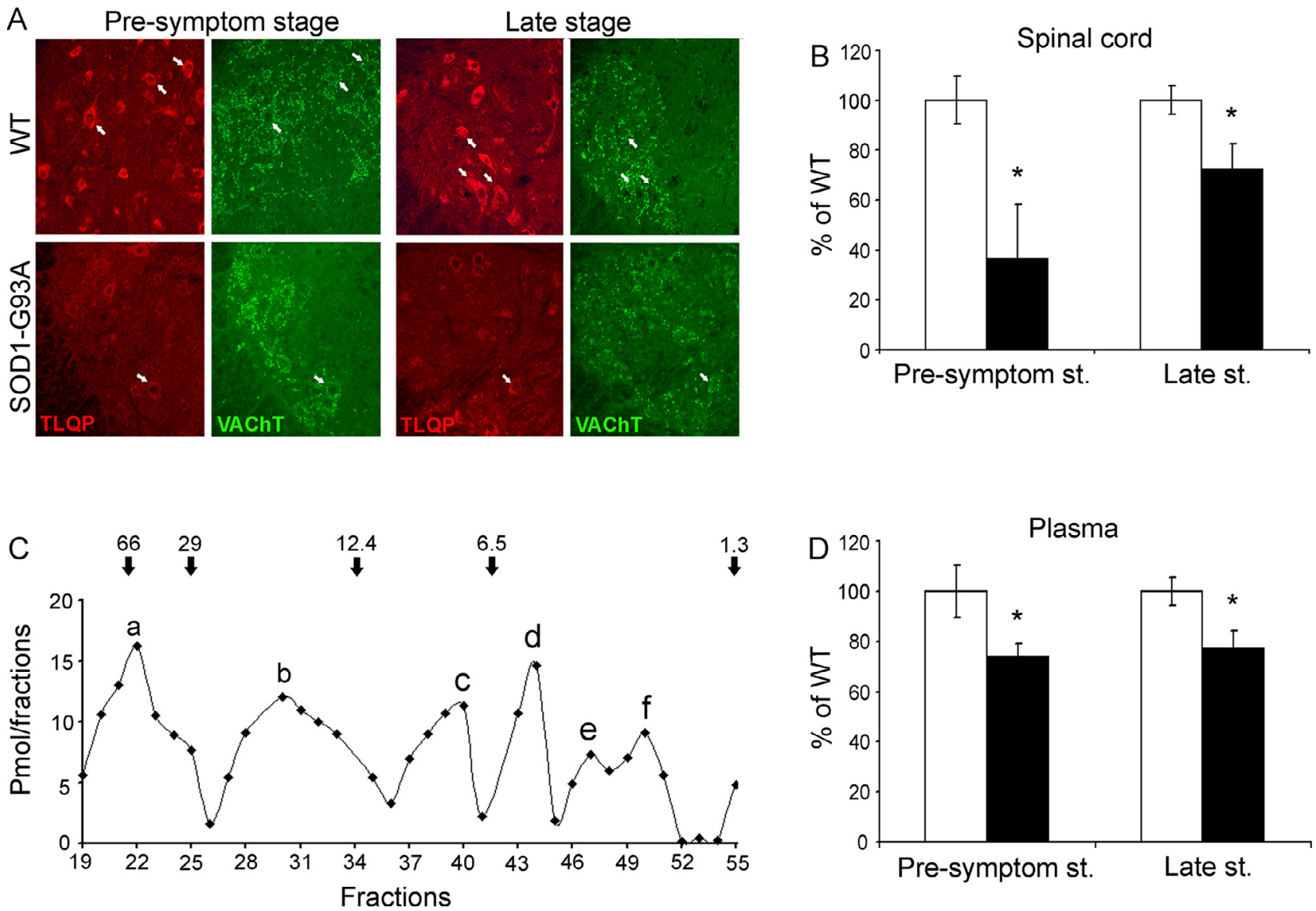

Fig. 4. TLQP peptides in mice. TLQP peptides in cervical motor neurons (A). TLQP peptides immunoreactivity (Cy3, red) is localized in a large number of perikarya of the ventral horns in wild-type mice in the age of the pre-symptomatic and late stage of transgenic mice. These cell bodies are identified as motor neurons using VAChT antibody (Alexa-488, green). Instead, in the SOD1-G93A mice, the TLQP immunoreactivity is weak visible in a minor number of cells already in the pre-symptomatic stage and remains reduced also in the late stage ( $n=3$ per genotype). Levels of TLQP peptides in cervical spinal cord (B). TLQP levels are significantly decreased in mutant mice (vs the corresponding wild type) already in the presymptomatic phase (percentage of decrease: about $70 ; p<0.005$ ) as well as in the late stage (18\%; $p<0.05)$. Data are expressed as percentage of the control samples (100\%), $n=7$ per genotype. Chromatography analysis coupled with ELISA in spinal cord (C). Different molecular forms are recognized by the TLQP antiserum: a. $\sim 66 \mathrm{kDa}$, compatible to the VGF precursor; b. $\sim 15 \mathrm{kDa}$ compatible to NAPP-129, and the peaks: c. $\sim 7-8$ $\mathrm{kDa}, \mathrm{d}$. $\sim 5 \mathrm{kDa}$, e. $\sim 3 \mathrm{kDa}$, and f. $\sim 2 \mathrm{kDa}$, compatible to TLQP-62, 42, 30 and 21, respectively. Arrows in the top indicates the molecular weight markers; pmol:picomoles. Levels of TLQP peptides in plasma (D). TLQP levels are significantly decreased in mutant mice vs wild type already in the pre-symptomatic phase $(26 \% ; p<0.05)$ as well as in the late stage $(23 \% ; p<0.05)$. Data are expressed as percentage of the control samples $(100 \%), n=7$ per genotype. (For interpretation of the references to color in this figure legend, the reader is referred to the web version of this article.)

death through oxidative stress (Duan et al., 2010; Braun et al., 2011; Zhan et al., 2015). Altogether, TLQP peptide/s change we observed probably occurred in connection with oxidative stress and ensuing pathophysiological mechanisms. This way, the TLQP alterations occurring in the spinal cord of pre-symptomatic SOD1 mice may be relevant part of, or respond to the early modifications triggering the waterfall of events that cause motor neuron degeneration. It is worth noting that TLQP peptides were localized in the bona fide Golgi area as well as in growth cones and axons (Chevalier-Larsen and Holzbaur, 2006). Golgi fragmentation has been shown to be associated with ALS hallmarks, and to occur at an early, preclinical stage in both ALS patients (Maruyama et al., 2010), and SOD1 mice (Vlug et al., 2005; Van Dis et al., 2014). In the same mice, defects in retrograde transport, from the muscle cells to the cell body of motor neurons, have been suggested to be one of the earliest visible alterations (Ligon et al., 2005).

\section{TLQP-21 protects neuronal cells from oxidative stress}

We here reported that the TLQP peptides, localized in the cytoplasm and growth cones/axons of the NSC-34 cells, decreased in response to oxidative stress, while the TLQP-21, when added in the medium, is able to protect the cells from the death. The other VGF peptides tested in the stressed NSC-34 cells were not reduced, or, if they were, did not protect the cells from the death (as in the case of the NERP-1). Since the presence of both TLQP peptides and gCq1-R within the NSC-34 cells, we could speculate that the neuroprotection could be due to mechanisms linked to their relationship. Actions of TLQP-21 via the $\mathrm{gC} 1 \mathrm{q}-\mathrm{R}$ receptor have been shown to be implicated in hypersensitivity in the spinal cord dorsal horn (Chen et al., 2013). The gC1q-R is a ubiquitous protein of $33 \mathrm{kDa}$ initially identified and characterized as a receptor for the globular heads of the complement activa- 
A Naive
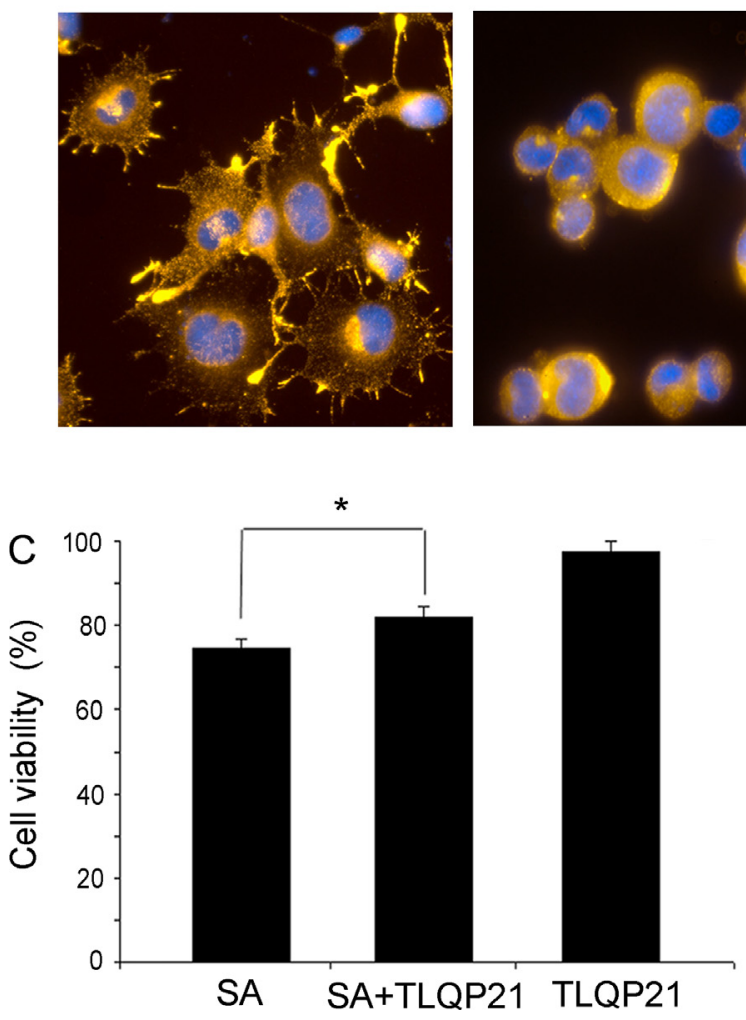

SA treated
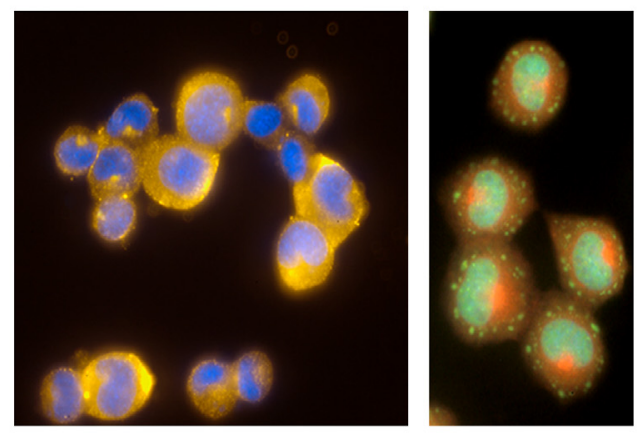

D

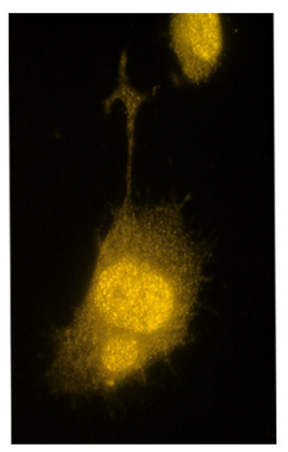

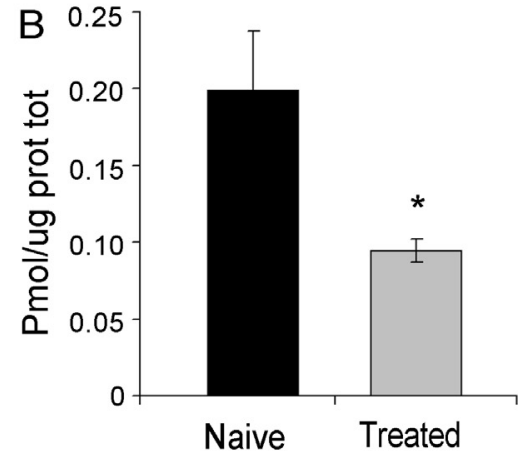

E $\quad k D a$

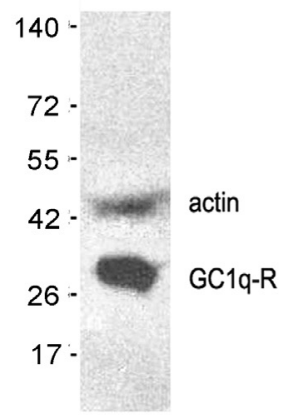

Fig. 5. TLQP peptides in NSC-34 cells. TLQP immunolocalization (A). TLQP peptides (Cy3, red-yellow) are found within the cytoplasm, probably in the Golgi area as well as in the axons and growth cones (left panel). When treated with Sodium Arsenite (SA), the cells lose their growth cones changing to a round shape (nucleus revealed in Blue: Hoechst 33342) and TLQP peptides are present exclusively within the cytoplasm (middle panel) and not visible in the stress granules (revealed with anti HuR, ALEXA488, green; right panel). TLQP levels (B). A significant TLQP peptides decrease is seen $(\mathrm{B})$ in the SA-treated compared to the naïve cells (about $53 \%, p<0.05$ ). Pmol/ $\mu \mathrm{g}$ prot tot: picomoles/micrograms of total protein. MTT viability test (C). The NSC-34 viability increases when the cells are treated with SA together with TLQP-21, compared to the treatment with the SA only (about $83 \%$ vs. $75 \%, p<0.05$ ). TLQP-21 alone is not able to produce any effect. The gC1q-R immunoreactivity (D, E). The gC1q-R antibody stains the nucleus as well as weakly the cytoplasm (D, Cy3 red-yellow), and also labeled a form of about 31-33 kDa revealed through Western blot $(E)$. (For interpretation of the references to color in this figure legend, the reader is referred to the web version of this article.)

tion component C1q (Ghebrehiwet et al., 1994) and involved in the inflammatory response (Peerschke and Ghebrehiwet, 2007). In spinal cord motor neurons of SOD1 mice, it was found to be detectable before the appearance of the clinical symptoms (Heurich et al., 2011) with a major expression at the late stage (Lee et al., 2013). TLQP-21 has been previously reported, as mentioned, to prevent apoptosis induced by oxidative stress in both human (Zhang et al., 2013) and rat cells (Severini et al., 2008). All together these pieces of evidences highly suggest an involvement of TLQP-21$\mathrm{gC} 1 \mathrm{q}-\mathrm{R}$ complex in the increased cell viability that we reported here, none the less, studies are warranted to investigate TLQP-21 activity on motor neurons in a variety of conditions. The $\mathrm{gC} 1 \mathrm{q}-\mathrm{R}$ is also expressed in fibroblasts (Bordin and Costa, 1998), where it might exert a protective action against oxidative stress (McGee and Baines, 2011). Hence, fibroblast cultures may be a further means to address the mechanisms implicated in TLQP-21 bioactivity, and its possible value in ALS.

Collectively, our study suggests that the TLQP family, including both TLQP-21 and TLQP-62, respond early to oxidative stress, and could be of value as a biological diagnostic index for ALS. The TLQP-21 peptide might be of some relevance to prevent or reduce motor neuron death. Further studies may be of interest, to address the possible relevance of TLQP peptides other than TLQP-21. TLQP-62 has so far better studied, and has been shown to have a role in neurogenesis (Thakker-Varia et al., 2014). Interestingly, in ALS patients, where impaired glucose tolerance has been reported (Sun et al., 2015), certain metabolites modulated in plasma are indicative of alterations in both mitochondrial activity and carbohydrate/lipid metabolism associated with neuronal changes (Lawton et al., 2012). Since TLQP-21 is a metabolic peptide acting on energy and lipolysis mechanisms (Bartolomucci et al., 2006), and TLQP-62 is a hypoglycemic agent (Petrocchi-Passeri et al., 2015), we could speculate that both peptides could be possibly involved in the energy mechanisms that contribute to motor neuron degeneration (Dupuis et al., 2004). In conclusion, although currently there are no applicable blood diagnostic tests and pharmacological treatments for ALS, research on these topics may likely include the TLQP family.

\section{AUTHORS' CONTRIBUTION}

$\mathrm{CB}, \mathrm{GLF}$ : conceived and planned the study; $\mathrm{CB}, \mathrm{BN}, \mathrm{RP}$ and $\mathrm{MB}$ performed experiments with assistance by $\mathrm{AB}$ 
and RP; $\mathrm{CB}, \mathrm{BN}$ and $\mathrm{CC}$ analyzed data; $\mathrm{MB}, \mathrm{FM}$ and $\mathrm{AV}$ contributed materials and analytical tools, and reviewed the manuscript; CB, CC and GLF wrote the paper. All authors read and approved the final version of the manuscript.

\section{ACKNOWLEDGMENTS}

Sandro Orrù provided fibroblast explants, Giuseppe Borghero human plasma samples. Giacomo Diaz is thanked for help with statistical analyses, Barbara Manconi for quality control of synthetic peptide preparations by HPLC-mass spectrometry, and Valeria Sogos for unceasing encouragement (all at the University of Cagliari, Cagliari, Italy). Angelo Poletti (University of Milan) provided the NSC-34 cell line. This work was supported by: the Autonomous Region of Sardinia (Sardinia PO FSE 2007-1013 funds, L.R. 7/2007); NeuroCare onlus; Interdisciplinary Human Movement and Rehab Research Laboratory (HuMoRe).

\section{CONFLICTS OF INTEREST}

Authors declare no conflict of interest that could prejudice the impartiality of this scientific work.

\section{REFERENCES}

Aguilar E, Pineda R, Gaytán F, Sánchez-Garrido MA, Romero M, Romero-Ruiz A, Ruiz-Pino F, Tena-Sempere M, Pinilla L (2013) Characterization of the reproductive effects of the VGF-derived peptide TLQP-21 in female rats: in vivo and in vitro studies. Neuroendocrinology 98:38-50.

Bartolomucci A, La Corte G, Possenti R, Locatelli V, Rigamonti AE, Torsello A, Bresciani E, Bulgarelli I, Rizzi R, Pavone F, D'Amato FR, Severini C, Mignogna G, Giorgi A, Schininà ME, Elia G, Brancia C, Ferri GL, Conti R, Ciani B, Pascucci T, Dell'Omo G, Muller EE, Levi A, Moles A (2006) TLQP-21, a VGF-derived peptide, increases energy expenditure and prevents the early phase of diet-induced obesity. Proc Natl Acad Sci U S A 103:14584-14589.

Behnke J, Cheedalla A, Bhatt V, Bhat M, Teng S, Palmieri A, Windon CC, Thakker-Varia S, Alder J (2017) Neuropeptide VGF promotes maturation of hippocampal dendrites that is reduced by single nucleotide polymorphisms. Int J Mol Sci 18:612.

Bergeron C (1995) Oxidative stress: its role in the pathogenesis of Amyotrophic Lateral Sclerosis. J Neurol Sci 129:81-84.

Boido M, Piras A, Valsecchi V, Spigolon G, Mareschi K, Ferrero I, Vizzini A, Temi S, Mazzini L, Fagioli F, Vercelli A (2014) Human mesenchymal stromal cell transplantation modulates neuroinflammatory milieu in a mouse model of Amyotrophic Lateral Sclerosis. Cytotherapy 16:1059-1072.

Bordin S, Costa LG (1998) Fibroblast heterogeneity of signal transduction mechanisms to complement-C1q. Analyses of calcium mobilization, inositol phosphate accumulation, and protein kinases-C redistribution. J Periodontol 69:642-649.

Bozdagi O, Rich E, Tronel S, Sadahiro M, Patterson K, Shapiro ML, Alberini CM, Huntley GW, Salton SR (2008) The neurotrophininducible gene VGF regulates hippocampal function and behavior through a brain-derived neurotrophic factor-dependent mechanism. J Neurosci 28:9857-9869.

Brancia C, Nicolussi P, Cappai P, La Corte G, Possenti R, Ferri GL (2005) Differential expression and seasonal modulation of VGF peptides in sheep pituitary. J Endocrinol 186:97-107.

Brancia C, Cocco C, D'Amato F, Noli B, Sanna F, Possenti R, Argiolas A, Ferri GL (2010) Selective expression of TLQP-21 and other VGF peptides in gastric neuroendocrine cells and modulation by feeding. J Endocrinol 207:329-341.

Brancia C, Noli B, Boido M, Boi A, Puddu R, Borghero G, Marrosu $F$, Bongioanni $P$, Orrù $S$, Manconi B, D'Amato $F$, Messana I, Vincenzoni F, Vercelli A, Ferri GL, Cocco C (2016) VGF protein and its C-terminal derived peptides in Amyotrophic Lateral Sclerosis: human and animal model studies. PLoS ONE 11(10).

Braun RJ, Sommer C, Carmona-Gutierrez D, Khoury CM, Ring J, Büttner S, Madeo F (2011) Neurotoxic 43-kDa TAR DNA-binding protein (TDP-43) triggers mitochondrion-dependent programmed cell death in yeast. J Biol Chem 286:19958-19972.

Cassina V, Torsello A, Tempestini A, Salerno D, Brogioli D, Tamiazzo L, Bresciani E, Martinez J, Fehrentz JA, Verdié P, Omeljaniuk RJ, Possenti R, Rizzi L, Locatelli V, Mantegazza F (2013) Biophysical characterization of a binding site for TLQP-21, a naturally occurring peptide which induces resistance to obesity. Biochim Biophys Acta 1828:455-460.

Cedarbaum JM, Stambler N, Malta E, Fuller C, Hilt D, Thurmond B, Nakanishi A (1999) The ALSFRS-R: a revised ALS functional rating scale that incorporates assessments of respiratory function. BDNF ALS Study Group (Phase III). J Neurol Sci 169:13-21.

Cero C, Vostrikov VV, Verardi R, Severini C, Gopinath T, Braun PD, Sassano MF, Gurney A, Roth BL, Vulchanova L, Possenti R, Veglia G, Bartolomucci A (2014) The TLQP-21 peptide activates the G-protein-coupled receptor C3aR1 via a folding-upon-binding mechanism. Structure 22:1744-1753.

Cero C, Razzoli M, Han R, Sahu BS, Patricelli J, Guo Z, Zaidman NA, Miles JM, O'Grady SM, Bartolomucci A (2016) The neuropeptide TLQP-21 opposes obesity via C3aR1-mediated enhancement of adrenergic-induced lipolysis. Mol Metab 6:148-158.

Chen YC, Pristerá A, Ayub M, Swanwick RS, Karu K, Hamada Y, Rice AS, Okuse K (2013) Identification of a receptor for neuropeptide VGF and its role in neuropathic pain. J Biol Chem 288:34638-34646.

Chevalier-Larsen E, Holzbaur ELF (2006) Axonal transport and neurodegenerative disease. Biochim Biophys Acta 1762:1094-1108.

Chiò A, Borghero G, Pugliatti M, Ticca A, Calvo A, Moglia C, Mutani R, Brunetti M, Ossola I, Marrosu MG, Murru MR, Floris G, Cannas A, Parish LD, Cossu P, Abramzon Y, Johnson JO, Nalls MA, Arepalli S, Chong S, Hernandez DG, Traynor BJ, Restagno G (2011) Large proportion of Amyotrophic Lateral Sclerosis cases in Sardinia due to a single founder mutation of the TARDBP gene. Arch Neurol 68:594-598.

Cocco C, Brancia C, Pirisi I, D’Amato F, Noli B, Possenti R, Ferri GL (2007) VGF metabolic-related gene: distribution of its derived peptides in mammalian pancreatic islets. J Histochem Cytochem 55:619-628.

Cocco C, D'Amato F, Noli B, Ledda A, Brancia C, Bongioanni P, Ferri GL (2010) Distribution of VGF peptides in the human cortex and their selective changes in Parkinson's and Alzheimer's diseases. J Anat 217:683-693.

D'Amato F, Noli B, Brancia C, Cocco C, Flore G, Collu M, Nicolussi P, Ferri GL (2008) Differential distribution of VGF-derived peptides in the adrenal medulla and evidence for their selective modulation. J Endocrinol 197:359-369.

D'Amato F, Noli B, Angioni L, Cossu E, Incani M, Messana I, Manconi B, Solinas P, Isola R, Mariotti S, Ferri GL, Cocco C (2015) VGF peptide profiles in type 2 diabetic patients' plasma and in obese mice. PLoS ONE 10(11).

DeJesus-Hernandez M, Mackenzie IR, Boeve BF, Boxer AL, Baker $M$, Rutherford NJ, Nicholson AM, Finch NA, Flynn H, Adamson J, Kouri N, Wojtas A, Sengdy P, Hsiung GY, Karydas A, Seeley WW, Josephs KA, Coppola G, Geschwind DH, Wszolek ZK, Feldman H, Knopman DS, Petersen RC, Miller BL, Dickson DW, Boylan KB, Graff-Radford NR, Rademakers R (2011) Expanded GGGGCC hexanucleotide repeat in noncoding region of C9ORF72 causes chromosome 9p-linked FTD and ALS. Neuron 72:245-256. 
Duan W, Li X, Shi J, Guo Y, Li Z, Li C (2010) Mutant TAR DNAbinding protein-43 induces oxidative injury in motor neuron-like cell. Neuroscience 169:1621-1629.

Dupuis L, Oudart H, Rene F, Gonzalez de Aguilar JL, Loeffler JP (2004) Evidence for defective energy homeostasis in amyotrophic lateral sclerosis: benefit of a high-energy diet in a transgenic mouse model. Proc Natl Acad Sci USA 101:11159-11164.

Ghebrehiwet B, Lim BL, Peerschke El, Willis AC, Reid KB (1994) Isolation, cDNA cloning, and overexpression of a $33-\mathrm{kD}$ cell surface glycoprotein that binds to the globular "heads" of C1q. J Exp Med 1(179):1809-1821.

Hannedouche S, Beck V, Leighton-Davies J, Beibel M, Roma G, Oakeley EJ, Lannoy V, Bernard J, Hamon J, Barbieri S, Preuss I, Lasbennes MC, Sailer AW, Suply T, Seuwen K, Parker CN, Bassilana F (2013) Identification of the C3a receptor (C3AR1) as the target of the VGF-derived peptide TLQP-21 in rodent cells. J Biol Chem 288:27434-27443.

Heurich B, El Idrissi NB, Donev RM, Petri S, Claus P, Neal J, Morgan $B P$, Ramaglia V (2011) Complement upregulation and activation on motor neurons and neuromuscular junction in the SOD1-G93A mouse model of familial Amyotrophic Lateral Sclerosis. J Neuroimmunol 235:104-109.

Jethwa PH, Warner A, Nilaweera KN, Brameld JM, Keyte JW, Carter WG, Bolton N, Bruggraber M, Morgan PJ, Barrett P, Ebling FJP (2007) VGF-derived peptide, TLQP-21, regulates food intake and body weight in Siberian hamsters. Endocrinology 148:4044-4055.

Lawton KA, Cudkowicz ME, Brown MV, Alexander D, Caffrey R, Wulff JE, Bowser R, Lawson R, Jaffa M, Milburn MV, Ryals JA, Berry JD (2012) Biochemical alterations associated with ALS. Amyotroph Lateral Scler 13:110-118.

Lee JD, Kamaruzaman NA, Fung JN, Taylor SM, Turner BJ, Atkin JD, Woodruff TM, Noakes PG (2013) Dysregulation of the complement cascade in the hSOD1-G93A transgenic mouse model of Amyotrophic Lateral Sclerosis. J Neuroinflamm 10:119.

Lewis JE, Brameld JM, Hill P, Cocco C, Noli B, Ferri G-L, Barrett PF, Ebling FJ, Jethwa PH (2017) Hypothalamic over-expression of VGF in the Siberian hamster increases energy expenditure and reduces body weight gain. PLoS One 12(2):24.

Ligon LA, LaMonte BH, Wallace KE, Weber N, Kalb RG, Holzbaur EL (2005) Mutant superoxide dismutase disrupts cytoplasmic dynein in motor neurons. NeuroReport 16:533-536.

Lin WJ, Jiang C, Sadahiro M, Bozdagi O, Vulchanova L, Alberini CM, Salton SR (2015) VGF and its C-terminal peptide TLQP-62 regulate memory formation in hippocampus via a BDNF-TrkBdependent mechanism. J Neurosci 35:10343-10356.

Maruyama H, Morino H, Ito H, IzumiY Kato H, Watanabe $Y(2010)$ Mutations of optineurin in Amyotrophic Lateral Sclerosis. Nature 465:223-226.

McGee AM, Baines CP (2011) Complement 1q-binding protein inhibits the mitochondrial permeability transition pore and protects against oxidative stress-induced death. Biochem J 433:119-125.

Moss A, Ingram R, Koch S, Theodorou A, Low L, Baccei M, Hathway GJ, Costigan M, Salton SR, Fitzgerald M (2008) Origins, actions and dynamic expression patterns of the neuropeptide VGF in rat peripheral and central sensory neurones following peripheral nerve injury. Mol Pain 4:62.

Noli B, Brancia C, D'Amato F, Ferri GL, Cocco C (2014) VGF changes during the estrous cycle: a novel endocrine role for TLQP peptides? PLoS ONE 9(10).

Noli B, Brancia C, Pilleri R, D'Amato F, Messana I, Manconi B, Ebling FJ, Ferri GL, Cocco C (2015) Photoperiod regulates vgf-derived peptide processing in Siberian hamsters. PLoS ONE 10(11).

Noli B, Sanna F, Brancia C, D'Amato F, Manconi B, Vincenzoni F, Messana I, Melis MR, Argiolas A, Ferri GL, Cocco C (2017) Profiles of VGF peptides in the rat brain and their modulations after phencyclidine treatment. Front Cell Neurosci 11:158.

Orrù S, Coni P, Floris A, Littera R, Carcassi C, Sogos V, Brancia C (2016) Reduced stress granule formation and cell death in fibroblasts with the A382T mutation of TARDBP gene: evidence for loss of TDP-43 nuclear function. Hum Mol Genet 25:4473-4483.

Pasinetti GM, Ungar LH, Lange DJ, Yemul S, Deng H, Yuan X, Brown RH, Cudkowicz ME, Newhall K, Peskind E, Marcus S, Ho L (2006) Identification of potential CSF biomarkers in ALS. Neurology 66:1218-1222.

Peerschke El, Ghebrehiwet B (2007) The contribution of gC1qR/p33 in infection and inflammation. Immunobiology 212:333-342.

Petrocchi-Passeri P, Cero C, Cutarelli A, Frank C, Severini C, Bartolomucci A, Possenti R (2015) The VGF-derived peptide TLQP-62 modulates insulin secretion and glucose homeostasis. J Mol Endocrinol 54:227-239.

Razzoli M, Bo E, Pascucci T, Pavone F, D'Amato FR, Cero C, Sanghez V, Dadomo H, Palanza P, Parmigiani S, Ceresini G, Puglisi-Allegra S, Porta M, Panzica GC, Moles A, Possenti R, Bartolomucci A (2012) Implication of the VGF-derived peptide TLQP-21 in mouse acute and chronic stress responses. Behav Brain Res 229:333-339.

Renton P, Speed J, Maddaford S, Annedi SC, Ramnauth J, Rakhit S, Bioorg Andrews J (2011) 1,5-Disubstituted indole derivatives as selective human neuronal nitric oxide synthase inhibitors. Med Chem Lett 21:5301-5304.

Rizzi R, Bartolomucci A, Moles A, D'Amato F, Sacerdote P, Levi A, La Corte G, Ciotti MT, Possenti R, Pavone F (2008) The VGFderived peptide TLQP-21: a new modulatory peptide for inflammatory pain. Neurosci Lett 441:129-133.

Robberecht W (2000) Oxidative stress in Amyotrophic Lateral Sclerosis. J Neurol 247(1):11-6.

Sabatelli M, Zollino M, Conte A, Del Grande A, Marangi G, Lucchini M, Mirabella M, Romano A, Piacentini R, Bisogni G, Lattante S, Luigetti M, Rossini PM, Moncada A (2015) Primary fibroblasts cultures reveal TDP-43 abnormalities in Amyotrophic Lateral Sclerosis patients with and without SOD1 mutations. Neurobiol Aging 36(5).

Severini C, Ciotti MT, Biondini L, Quaresima S, Rinaldi AM, Levi A, Frank C, Possenti R (2008) TLQP-21, a neuroendocrine VGFderived peptide, prevents cerebellar granule cells death induced by serum and potassium deprivation. J Neurochem 104:534-544.

Soltys MJ, Kang D, Gupta RS (2000) Localization of P32 protein $(\mathrm{gC} 1 \mathrm{q}-\mathrm{R})$ in mitochondria and at specific extramitochondrial locations in normal tissues. Histochem Cell Biol 114:245-255.

Sun Y, Lu CJ, Chen RC, Hou WH, Li CY (2015) Risk of Amyotrophic Lateral Sclerosis in patients with diabetes: a nationwide population-based cohort study. J Epidemiol 25:445-451.

Thakker-Varia S, Behnke J, Doobin D, Dalal V, Thakkar K, Khadim F, Wilson E, Palmieri A, Antila H, Rantamaki T, Alder J (2014) VGF (TLQP-62)-induced neurogenesis targets early phase neural progenitor cells in the adult hippocampus and requires glutamate and BDNF signaling. Stem Cell Res 12:762-777.

Trani E, Giorgi A, Canu N, Amadori G, Rinaldi AM, Halban PA, Ferri $G L$, Possenti R, Schininà ME, Levi A (2002) Isolation and characterization of VGF peptides in rat brain. Role of $P C 1 / 3$ and PC2 in the maturation of VGF precursor. J Neurochem 81:567-574.

Tremolizzo L, Pellegrini A, Conti E, Arosio A, Gerardi F, Lunetta C, Magni P, Appollonio I, Ferrarese C (2016) BDNF serum levels with respect to multidimensional assessment in Amyotrophic Lateral Sclerosis. Neurodegener Dis 16:192-198.

Turner MR, Kiernan MC, Leigh PN, Talbot K (2009) Biomarkers in Amyotrophic Lateral Sclerosis. Lancet Neurol 8:94-109.

Van Dis V, Kuijpers M, Haasdijk ED, Teuling E, Oakes SA, Hoogenraad CC (2014) Golgi fragmentation precedes neuromuscular denervation and is associated with endosome abnormalities in SOD1-ALS mouse motor neurons. Acta Neuropathol Commun 2:38

Vlug AS, Teuling E, Haasdijk ED, French P, Hoogenraad CC, Jaarsma D (2005) ATF3 expression precedes death of spinal motoneurons in amyotrophic lateral sclerosis-SOD1transgenic mice and correlates with C-Jun phosphorylation, CHOP expression, somato-dendritic ubiquitination and Golgi fragmentation. Eur J Neurosci 22:1881-1894. 
Yang S, Zhang KY, Kariawasam R, Bax M, Fifita JA, Ooi L, Yerbury JJ, Nicholson GA, Blair IP (2015) Evaluation of skin fibroblasts from Amyotrophic Lateral Sclerosis patients for the rapid study of pathological features. Neurotox Res 28:138-146.

Zarei S, Carr K, Reiley L, Diaz K, Guerra O, Altamirano PF, Pagani W, Lodin D, Orozco G, Chinea A (2015) A comprehensive review of Amyotrophic Lateral Sclerosis. Surg Neurol Int 6:171.

Zhan L, Xie Q, Tibbetts RS (2015) Opposing roles of p38 and JNK in a Drosophila model of TDP-43 proteinopathy reveal oxidative stress and innate immunity as pathogenic components of neurodegeneration. Hum Mol Genet 24:757-772.

Zhang $\mathrm{W}, \mathrm{Ni}$ C, Sheng J, Hua Y, Ma J, Wang L, Zhao Y, Xing Y (2013) TLQP-21 protects human umbilical vein endothelial cells against high-glucose-induced apoptosis by increasing G6PD expression. PLoS ONE 8(11).

Zhao Z, Lange DJ, Ho L, Bonini S, Shao B, Salton SR, Thomas S, Pasinetti GM (2008) VGF is a novel biomarker associated with muscle weakness in Amyotrophic Lateral Sclerosis (ALS), with a potential role in disease pathogenesis. Int J Med Sci 5:92-99.

Table 1A. Characteristics of patients.

\begin{tabular}{|c|c|c|c|c|c|}
\hline P\# & Age & Gender & ALSFRS-R Score & Genetic mutation & Co-morbidity \\
\hline 1 & 67 & $\mathrm{M}$ & 25 & TDP-43 A382T & \\
\hline 2 & 66 & $\mathrm{~F}$ & 19 & TDP-43 A382T & \\
\hline 3 & 81 & $\mathrm{~F}$ & 30 & nd & MDS \\
\hline $4^{*}$ & 39 & $\mathrm{~F}$ & 22 & TDP-43 A382T & \\
\hline 5 & 56 & $\mathrm{~F}$ & 43 & SOD1 & \\
\hline $6^{*}$ & 66 & $\mathrm{~F}$ & 14 & TDP-43 A382T & \\
\hline 7 & 82 & M & 21 & nd & \\
\hline 8 & 72 & $\mathrm{~F}$ & 22 & TDP-43 A382T & \\
\hline $9^{*}$ & 53 & $M$ & 28 & nd & \\
\hline $10^{*}$ & 72 & $\mathrm{M}$ & 11 & C9ORF expansion & \\
\hline 11 & 48 & $M$ & 26 & TDP-43 A382T & \\
\hline $12^{*}$ & 64 & $M$ & 27 & nd & \\
\hline 13 & 56 & $M$ & 41 & C9ORF expansion & DVT \\
\hline 14 & 71 & $\mathrm{M}$ & 42 & SOD1 & \\
\hline $15^{*}$ & 55 & $\mathrm{M}$ & 21 & TDP-43 A382T & \\
\hline 16 & 64 & $\mathrm{~F}$ & 38 & SOD1 & \\
\hline 17 & 78 & $M$ & 17 & TDP-43 A382T & \\
\hline $18^{*}$ & 42 & $\mathrm{~F}$ & 30 & nd & \\
\hline 19 & 53 & $\mathrm{~F}$ & 31 & nd & \\
\hline 20 & 65 & $\mathrm{~F}$ & 38 & C9ORF72 expansion & \\
\hline 21 & 70 & $M$ & 15 & nd & \\
\hline $22^{*}$ & 69 & M & 6 & TDP-43 A382T & \\
\hline 23 & 70 & $\mathrm{~F}$ & 31 & TDP-43 A382T & psychosis \\
\hline $24^{*}$ & 82 & M & 23 & TDP-43 A382T & \\
\hline $25^{*}$ & 76 & $\mathrm{~F}$ & 20 & TDP-43 A382T & \\
\hline $26^{\star}$ & 61 & M & 35 & nd & \\
\hline 27 & 45 & M & 41 & TDP-43 A382T & \\
\hline 28 & 53 & $\mathrm{~F}$ & 25 & nd & \\
\hline $29^{*}$ & 64 & $M$ & 30 & nd & \\
\hline 30 & 76 & $M$ & 32 & nd & \\
\hline $31^{*}$ & 64 & $M$ & 17 & nd & \\
\hline $32^{*}$ & 53 & $\mathrm{M}$ & 37 & nd & \\
\hline 33 & 72 & $M$ & 35 & TDP-43 A382T & \\
\hline 34 & 58 & $\mathrm{M}$ & 33 & ndr & \\
\hline 35 & 52 & $M$ & 41 & C9ORF72 expansion & \\
\hline 36 & 67 & $M$ & 16 & nd & $\mathrm{K}$ colon \\
\hline $37^{*}$ & 72 & $\mathrm{~F}$ & 23 & C9ORF72 expansion & \\
\hline $38^{*}$ & 74 & $\mathrm{~F}$ & 32 & nd & \\
\hline 39 & 67 & $\mathrm{~F}$ & 21 & TDP-43 A382T & Sjögren's syndrome \\
\hline 40 & 74 & $\mathrm{~F}$ & 21 & nd & \\
\hline $41^{*}$ & 59 & $\mathrm{~F}$ & 27 & nd & \\
\hline $42^{*}$ & 64 & $\mathrm{~F}$ & 16 & nd & \\
\hline $43^{*}$ & 63 & $\mathrm{~F}$ & 0 & nd & \\
\hline 44 & 65 & $M$ & 32 & TDP-43 A382T & Parkinsonism \\
\hline
\end{tabular}

" Late stage of ALS disease; nd: not determined; DVT: deep vein thrombosis; MDS: Myelodysplastic syndrome. 